\title{
Investigation of the Present Situation of China's Private Enterprise Internal Audit and the Study of Improvement Measures
}

\author{
Yongchen LI \& Jingxiong TANG \\ School of Economic Management, North China Electric Power University (Baoding), No.689, Huadian Road, \\ North District, Baoding, Hebei Province, China 071000
}

\begin{abstract}
Along with our country socialist market economy unceasing development, the reform unceasing deepening, the private enterprise obtained the development opportunity which front has not had, According to the statistics, our country Enterprise above $90 \%$ is the family firm. Many private enterprises all are evolve directly from the family business management pattern, lacks the systematization, specialized and the standardized management, the internal surveillance mechanism is not perfect, this has restricted private enterprise's development and the consummation seriously. This article first explained internal audit definition, had pointed out internal audits own value. Secondly, combining with the present situation of private enterprises in the analysis of the existing internal audit in private family enterprise problem, aimed at these questions to propose once more some concrete solution, final this article has carried on the discussion to the future family type private enterprise's internal audit trend of development.
\end{abstract}

KEYWORD: diversified development; internal Audit; management; private enterprise; quality of personnel

\section{INTRODUCTION}

\subsection{The definition of private enterprise}

Private enterprises have narrow and broad cent .The generalized private enterprises in addition to the "national economy" all business entities outside the narrow sense of private enterprises, both privately owned and privately, including state-owned private, such as Joint stock; refers to the individual enterprises, private enterprises and partnership enterprises, enterprise property owned by the private enterprises. This article the main object is in the narrow sense of private enterprises.

\subsection{Characteristics of China's private enterprises}

\subsubsection{Enterprises owned by one or a small number of investors.}

Corporate ownership of one or a small number of investors in all its corporate shares continue to decentralized social. Therefore, private enterprises from the whole, although its market-oriented high degree of operating flexibility, and lighten the burden of social advantage, but China's private enterprises in the development, but also inevitably there are some problems.

\subsubsection{The family enterprise system is the main body of the operation of enterprises.}

Majority of the implementation of China's private family business is a unilateral governance structure, and this structure is characterized by a private family business CEOs both corporate property owners while corporate managers. They have these important rights of the residual claim, management rights and other enterprises, and their family members are often also arranged various important positions.

\subsubsection{Completely market-oriented}

Private enterprises operating objective is to achieve capital appreciation, and the pursuit of capital gains is to maximize its interests Reinvestment inherent desire to invest in order to achieve further asset value. In this goal driven, private enterprise the biggest feature is its operating activities fully market-oriented, the transfer of capital to the market need, the capital to invest in industries with high marginal production.

\subsubsection{Flexibility and competitive}

Private enterprises as China's non-mainstream economy and therefore cannot be preferential policies as state-owned enterprises as the support they need to survive in the market and development 
you need to have a strong competitive. With suitable private enterprises in investment, production, distribution, showed a great deal of flexibility. No strict control standards, physical system can be flexibly adjusted to meet market demand.

\section{METHODOLOGY}

\subsection{Private enterprise survey data of Shaoxing in Zhejiang province}

According to statistics, more than $90 \%$ of China's enterprises for family businesses, visible, family business have become a kind of important form. Thus,establishing internal audit system will become the inevitable choice for enterprise development.

According to a 100 survey data of private enterprises in Shaoxing, zhejiang province, there are 44 in the survey were surveyed, including 22 conducted internal audit work, 9 have full-time audit institutions , 10 not have a full-time audit institutions but have full time auditors, the other three for part-time workers.

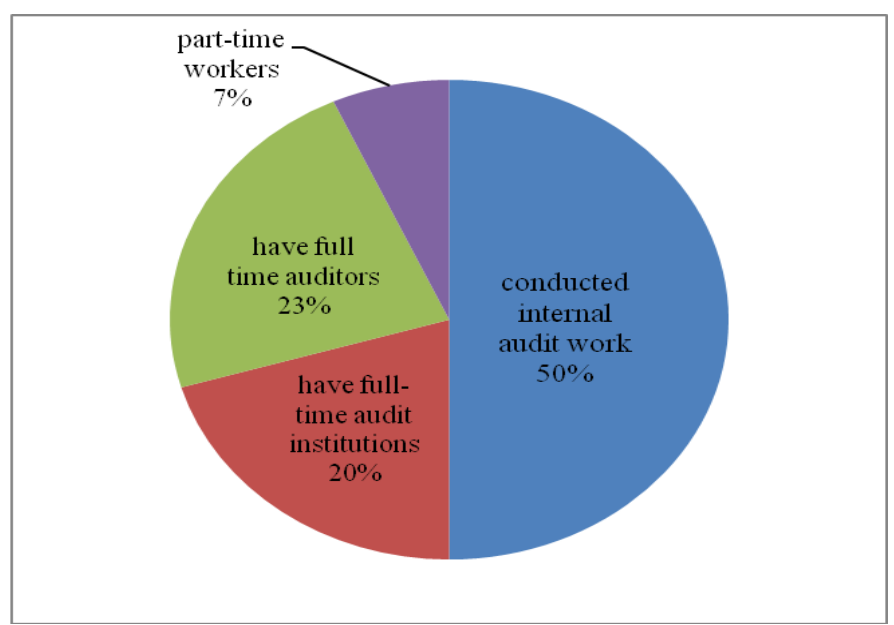

Fig.1 Survey Data of private enterprises in Shaoxing

When talked about the cause of the internal audit set up, there are 20 companies considered the needs of the development of internal, only two are act or for other reasons. 22 in the internal audit is 14 of the financial audit, is applied on the eight economic efficiency audit, 11 of the internal control review, six of the economic responsibility audit. Visible, internal audit got some private enterprise the attention of the private enterprises still exists many problems.

\subsection{Analysis of the overall situation of China's private enterprises}

Awareness of internal audit in private enterprises is different in different areas and different enterprises. Good private enterprise at present, the internal audit work development is concentrated in the more developed area economy, such as Zhejiang,
Guangdong) of large and medium-sized corporation group co., LTD, which is set most of the private enterprise internal audit institutions, in accordance with the requirements in carrying out internal audit work. But in some economic in less developed provinces, the private enterprise internal audit only in its infancy, and even in some provinces, has yet to have private enterprises to set up an independent internal audit department, and in the same province of the same level of private enterprise, treatment of internal audit has a very big difference.

\section{RESULTS}

\subsection{There is a misunderstanding in private business owner's awareness}

The importance of the internal audit has not been universal attention to the private business owners, at the same time there is a misunderstanding in Private business owner' s awareness

As the owners of private enterprises has absolute control in terms of material, financial, human and other disposable rights, since that internal audit is not essential. The most private company CEOs influenced by family management mode and experience in management thinking deep branch between the various bodies of the family business, have a more or less family relations, property owners and managers of economic responsibility not fuzzy relationship clear, between the upper and lower levels harbored seriously hampered the development of internal audit.

\subsection{Internal audit lacks of theoretical guidance}

Due to the rapid development of private enterprises in China, and the development of the theory of internal audit related research private enterprises but relatively slow, resulting in the lack of private enterprise internal audit carried out the corresponding theoretical guidance, private enterprises can only be simple to apply state-owned enterprises or foreign The audit institutions set mode. The audit approach is very traditional, rigid, audit means seriously lagging behind in the development of the accounting work, leading to the audit concept there is a considerable gap between the objectives and scope of international internal audit.

\subsection{Setting problems of enterprise internal audit institutions}

The internal audit of the private enterprise without government guidance and legal norms is to emulate the behavior of companies based solely on its effectiveness and take an active. Whether to set up internal audit institutions, as well as how to set up the objective need depends entirely on the owner's 
personal wishes and enterprise development. Thus, the authority and independence of the internal audit agency usually greatly reduced, auditors play a role in the space and freedom of work may be considerable constraints.

\subsection{Internal audit uneven quality of personnel}

Internal audit work related to all aspects of business, some important secrets, so some private enterprises dare not let family members other than the person responsible for the company's internal audit, which makes private enterprises subject to considerable restrictions on hiring talent people. The quality of the internal audit staff determines the quality of the internal audit of the private enterprises, most private enterprises internal audit staffs are not familiar with the internal audit work to, just hold a simple review of the accounting information and check, not fully play the important value of internal audit in the enterprise.

\subsection{Internal audit methods are backward}

Auditing standards and operating guidelines of private enterprises has not yet worked out, can only refer to a national audit and social audit practices, operating on the lack of procedural and normative audit methods are backward, a lot of enterprises still remain based in the traditional manual audit on audit inefficient. With enterprise economies of scale, the expansion of the scope of investment, corporate audit only far unable to meet the needs of enterprise development in the financial audit.

\section{SOLUTIONS ON PRIVATE ENTERPRISES INTERNAL AUDIT PROBLEMS}

\subsection{Deepening understanding of the business owners}

To continue to deepen the understanding of the private business owners, and guide enterprises to strengthen the construction of internal audit, most of the private enterprises in the internal audit institutions are carried out directly by the president or general manager of the company leadership, they can be given to the internal audit agencies broad powers, such as Young or group co., LTD, president of audit non-restricted area "thought, require audit department of the company affiliated enterprises overseas marketing branch audit, the Group company itself addition to audit and private business owners can learn from this "audit restricted area" thinking.

\subsection{Strengthen theoretical research}

Change the current backward situation of theory research is the key to develop the private enterprise internal audit. Private enterprises should actively cooperation and scientific research units to create a theoretical research space for private enterprise internal audit, theoretical research results can be applied to the practice of internal audit. The internal audit is still there "audit based on the lack of" serious phenomenon, which should focus on strengthening the legal publicity space to private enterprise internal audit in the practice of architecture and the audit on the theoretical framework, internal audit of private enterprises include the National Audit operational guidance range.

\subsection{Rational design of internal audit mechanism}

Maintain the objectivity of auditors and the relative independence is the focus of private enterprises to adopt what kind of audit mode. The key is to be in line with the form of enterprise management system, and the scale of operation. For small enterprises should choose the internal audit of externalizing itself does not establish an internal audit institutions, and business to accounting firms, businesses are required to establish an internal audit supervisor to supervise the execution of audit work, play a communication and business management CPA's role as a bridge. For the large-scale private enterprise can adopt double internal audit organization pattern.

\subsection{Improve the quality of personnel}

The composition of the internal audit staff should be diversified. Internal audit staff should not only proficient in accounting, auditing, taxation, foreign trade, financial and other aspects of knowledge but also should be very familiar with the operation and management, engineering technology, process, economic and legal aspects of knowledge. Private enterprises should select from a number of professional audit staff, and to increase the number of professionals such as engineering, management, the proportion of the staff of the legal profession, continuing education and training of internal audit staff must also receive attention.

\subsection{Improve the auditing mode}

Expanding the functions of the audit on the basis of the traditional financial audit, and actively carry out operational audits, management audits, economic responsibility audit, risk management audit to help companies to reduce and avoid risks and maximize the intrinsic value of the internal audit. While using the computer to carry out the internal audit, established within a complete and efficient auditing 
operating platforms and information systems, the audit from the a single post audit things combine prior audit, effective monitoring of the enterprises internal financial and accounting work and evaluation.

\section{THE TREND OF THE DEVELOPMENT OF PRIVATE ENTERPRISE INTERNAL AUDIT IN OUR COUNTRY}

\subsection{The development direction of internal audit content}

Private internal audit will focus from the traditional financial audit to the development of the following aspects:

(1) Operating audit, it is based on the audit unit business activities to the specific object of the audit, the evaluation of the degree of utilization of the various elements of productivity, in order to explore the potential to improve the economic benefits of an audit.

(2) Management audit, which is in oader to improve the quality of management and improve the management level of the enterprise, review of audited units in the planning, organization, leadership, control, decision-making and other management functions and promote the audited entity to improve the management level, promote better co-ordination of the factor of production, in order to improve the economic efficiency of the audit.

(3) Economic responsibility audit, economic responsibility audits the internal audit staff to bear the economic responsibility of the responsible person in the operating results of his responsibility during an audit of the evaluation. Private enterprises according to their own needs and to learn from the experience of state-owned enterprises audit system settings set within the enterprise cost center, profit center, revenue center, investment center, to determine the interests and responsibilities of the various persons responsible for its operations through the performance appraisal results.

(4) Strategic audit, which is an urgent need, internal audit, audit and evaluation of product sales market, the nature of the organization and management of the market image of the organization, operation mechanism and strategic issues, to help organizations reduce to avoid market risks, access to strategic advantage, so the introduction of strategic audit.

(5) Risk management audit, it refers to the internal audit department to adopt a systematic, disciplined approach to risk management information system to test, risk identification, analysis and evaluation of the business cycle, and relevant departments, management and processing based on a series of audit activities, the agency's risk management, control and supervision of the process of evaluation and to improve process efficiency and help organizations achieve goals.

\subsection{Internal auditors in the knowledge structure to hold diversified direction}

Internal auditors should not only familiar with accounting, auditing, taxation, foreign trade, financial and other aspects of knowledge, but also should be very familiar with the business management, engineering, process flow, economic and legal aspects of knowledge. Enterprises will strengthen the training and education work of the internal audit staff, improve the overall quality of their ability and team, to meet the need of high level of audit work.

\section{CONCLUSION}

Internal audit as an important component of the enterprise development is bound to be more and more the attention of private business owners, corporate development in order to survive in the fierce competition in the market must establish a sound system of internal audit, we must first locate the setting mode of the internal audit agency staffed with qualified audit staff, followed by the internal audit function should from single to multiple developments in the scope of the internal audit by the financial revenue and expenditure audit to the development of economic benefit audit, internal auditors should audit type to compound development. Only continue to advance with the times, in order to better adapt to the needs of private enterprise development and improvement internal audit.

\section{REFERENCES}

[1] Annukka Jokipii. Determinants and consequences of internal control in firms: a contingency theory based analysis. Journal of Management \& Governance . 2010 (2)

[2] Marc Sim.National culture effects on groups evaluation internal control. Manag erial AuditingJournal . 2010

[3] Tian Daqiong.Private enterprise internal audit problem" contained in the of contemporary economic.2011,18 (in Chinese)

[4] Du Juling.Private enterprise internal audit of the status quo and Countermeasures Analysis" contained in the. Friends of Accounting 7, 2011 (in Chinese)

[5] Sally. On the units internal audit role and the status quo," contained in the "management information.18, 2011 (in Chinese) 